Article

\title{
A Zn(II) Metallocycle as Platform to Assemble a 1D + 1D $\rightarrow$ 1D Polyrotaxane via $\pi \cdots \pi$ Stacking of an Ancillary Ligand
}

\author{
Marzio Rancan 1,*(D), Giada Truccolo ${ }^{2}$, Alice Carlotto ${ }^{2}\left(\mathbb{D}\right.$, Silvio Quici ${ }^{3}$ and Lidia Armelao ${ }^{1,2}$ \\ 1 Institute of Condensed Matter Chemistry and Technologies for Energy (ICMATE), National Research \\ Council (CNR), c/o Department of Chemical Sciences, University of Padova, via Marzolo 1, \\ 35131 Padova, Italy; lidia.armelao@unipd.it \\ 2 Department of Chemical Sciences, University of Padova, via Marzolo 1, 35131 Padova, Italy; \\ giadatruccolo87@gmail.com (G.T.); alice.carlotto@phd.unipd.it (A.C.) \\ 3 Institute of Molecular Science and Technologies (ISTM), National Research Council (CNR), Via C. Golgi 19, \\ 20133 Milano, Italy; silvio.quici@istm.cnr.it \\ * Correspondence: marzio.rancan@unipd.it; Tel.: +39-049-8275188
}

Received: 27 September 2019; Accepted: 8 November 2019; Published: 15 November 2019

\begin{abstract}
A new $\left[\mathrm{Zn}_{2} \mathrm{~L}_{2}\right]$ metallocycle bearing two metal centers that can coordinate ancillary ligands and a pocket suitable to host guest molecules is reported. These two features are exploited by reacting the metallocycle with a pyridine ligand to self-assemble in the solid state an extended intertwined system with the rare $1 \mathrm{D}+1 \mathrm{D} \rightarrow 1 \mathrm{D}$ topology. This interpenetrated architecture is supported by $\pi \cdots \pi$ stacking between two pyridine units of two different metallocycles in the pocket of a third metallocycle.
\end{abstract}

Keywords: polyrotaxane; metallocycle; metalloring; self-assembly; pi stacking; zinc; ancillary ligand

\section{Introduction}

MIMAs, mechanically interlocked molecular architectures, i.e., molecules that are entangled as a consequence of their topology, have attracted increasing attention [1]. They play a crucial role in natural systems, but also to exploit intriguing topologies, such as catenanes, rotaxanes, knots, and other supramolecular architectures, toward molecular machines [1]. In this context, coordination rings and cages with peculiar host-guest properties are ideal starting units to develop new intertwined architectures. Fujita et al. first reported a [2]catenane that quantitatively self-assembled starting from two Pd(II)-1,4-bis((4-pyridyl)methyl)benzene-based rings [2], and few years later, the first example of two interlocked coordination-driven cages [3]. Thereafter, the possibility to obtain catenane-like species starting from metallo-rings or -cages has been reported by several authors. In particular, pyridyl-based ligands together with square-planar metal cations (e.g., $\mathrm{Pd}(\mathrm{II})$ ) are the most common building blocks for the construction of interlocked systems as recently reviewed [4]. On the other hand, the self-assembly of extended intertwined architectures, such as rotaxane oligomers [5-7], poly-pseudo-rotaxanes [8], or polyrotaxanes [9-11], is less common. Winpenny et al. have used the monoanionic $\left[\mathrm{Cr}_{7} \mathrm{NiF}_{8}\left(\mathrm{O}_{2} \mathrm{CtBu}\right)_{16}\right]^{-}$ring to elegantly synthesize main-chain $[n]$ rotaxane oligomers $[5,6]$, a daisy chain [7] and a $1 \mathrm{D}$ polyrotaxane [11]. Lu et al. [8] reported the first example of a 2D poly-pseudo-rotaxane developed starting from a discrete stool-like metallocycle. Metallorings, based on transition metals capable of expanding their coordination, can be used as platforms to hierarchically assemble extended metallo-supramolecular systems [12-15] as demonstrated by Lindoy et al. This strategy has also allowed to isolate a 1D polyrotaxane, where a copper-based metallocycle and a 
pyridyl bridging ligand self-assemble to form a 1D coordination polymer (the axle) and a discrete rectangular box (the stopper) [10].

In order to design metallocycles bearing metal ions that can change their coordination sphere by ligand substitution or by expanding the coordination number, $2+$ charged metal ions and bis- $\beta$-diketone ligands have been proven to be ideal building blocks [12-15]. For instance, we have previously demonstrated that $\mathrm{Cu}$ (II) and a bis- $\beta$-diketone can be used to self-assemble a constitutional dynamic library of metallocycles [16], where the interactions with $\sigma$-donor guests via $\mathrm{Cu}-\mathrm{N}$ bonds drive the system toward a triangular metallobox $[17,18]$ that can be used also to catalyze host reactions [19]. We recently described a new $\left[\mathrm{Cu}_{2} \mathrm{~L}_{2}\right]$ metallocycle, where $\mathrm{L}$ is the bis- $\beta$-diketone 1-(4-\{[4-(3-oxo-3-phenylpropanoyl)phenyl]methyl\}phenyl)-3-phenylpropane-1,3-dione. This metallocycle self-assembles in an interlocked $1 \mathrm{D}+1 \mathrm{D} \rightarrow 1 \mathrm{D}$ polyrotaxane when reacted with the bridging ancillary ligand 4, $4^{\prime}$-bipyridine (bipy) [9]. In the polyrotaxane, bipy is the guest-axle and $\left[\mathrm{Cu}_{2} \mathrm{~L}_{2}\right]$ acts as the stopper as well as the hosting ring. The process is reversible since a coordinating solvent can disassemble the polyrotaxane substituting the bipy ligand. Hence, the proposed strategy to develop intertwined structures starting from metallocycles is to design and synthesize a system with two main features: (i) metal centers apt to expand their coordination sphere and (ii) host-guest properties, Figure 1a. Such key features are exploited by reacting the metallocycle with suited ligands that drive the assembly of the intertwined system by threading and coordinating the metallocycle. In our previous study [9], the formation of the 1D + 1D $\rightarrow 1 \mathrm{D}$ interpenetrated polyrotaxane was essentially driven by the bridging coordination properties of the 4,4'-bipyridine that connects two metallocycles and, at the same time, is hosted by a third metallocycle, as depicted in Figure $1 b$. Herein, we report a similar metallocycle based on $\mathrm{Zn}(\mathrm{II})$ and $\mathrm{L}$, $\left[\mathrm{Zn}_{2} \mathrm{~L}_{2}\right]$. Adducts with three different alcohols $(\mathrm{MeOH}, \mathrm{EtOH}$, and $i \mathrm{PrOH}$ ) were obtained. Following the described approach, $\left[\mathrm{Zn}_{2} \mathrm{~L}_{2}\right]$ reacts with pyridine (py) and self-assembles to form an interpenetrated polyrotaxane with the rare $1 \mathrm{D}+1 \mathrm{D} \rightarrow 1 \mathrm{D}$ topology. Such interpenetrated architectures are supported by $\pi \cdots \pi$ stacking of the ancillary ligand, Figure 1c.

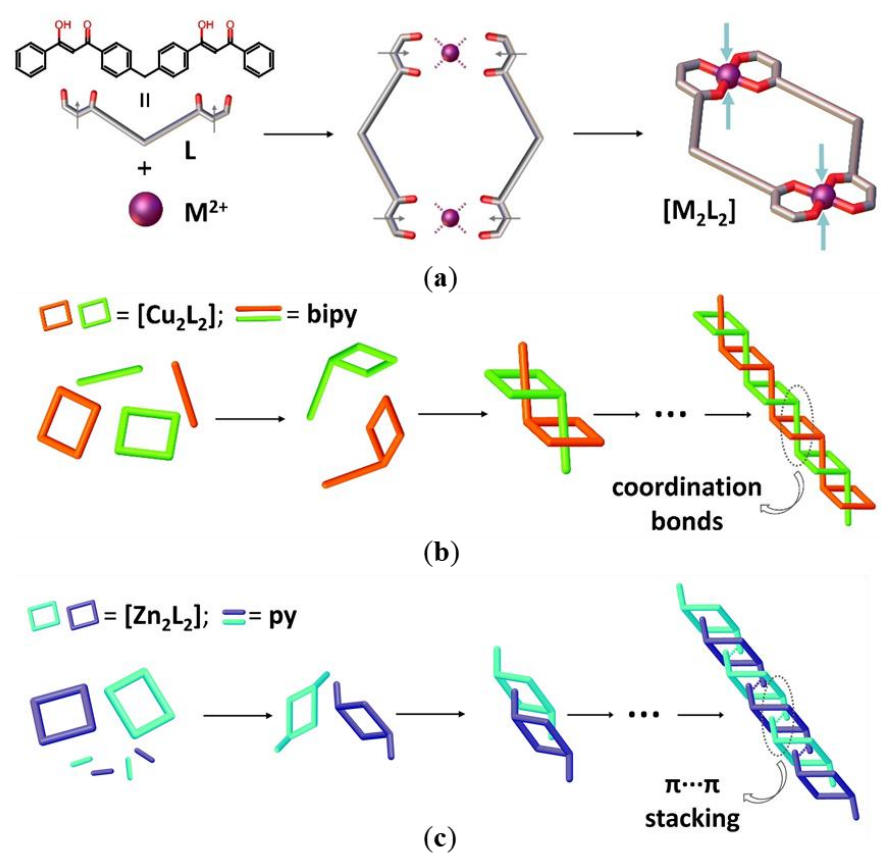

Figure 1. (a) Design of metallocycles that can expand metal ions' coordination sphere with ancillary ligands. (b) Self-assembly of a 1D $+1 \mathrm{D} \rightarrow 1 \mathrm{D}$ interpenetrated polyrotaxane driven by the formation of coordination bonds with a $\left[\mathrm{Cu}_{2} \mathrm{~L}_{2}\right]$ metallocycle, previous work (Reproduced with permission from [9]. 2019, Royal Society of Chemistry). (c) Self-assembly of a 1D + 1D $\rightarrow$ 1D interpenetrated polyrotaxane driven by $\pi \cdots \pi$ stacking with a $\left[\mathrm{Zn}_{2} \mathrm{~L}_{2}\right]$ metallocycle, present work. 


\section{Results and Discussion}

Metallocycle [ $\mathrm{Zn}_{2} \mathrm{~L}_{2}$ ] was synthesized in quantitative yield by combining a chloroform solution of L with a methanol $(\mathrm{MeOH})$ zinc acetate solution in equimolar amount. Colorless needle-like single crystals of $\left\{\left[\mathrm{Zn}_{2} \mathrm{~L}_{2}(\mathrm{MeOH})_{2}\right] \cdot 2\left(\mathrm{CHCl}_{3}\right)\right\}, \mathbf{1}$, were obtained by the reactants diffusion technique of the two building blocks (zinc acetate in methanol and $\mathrm{L}$ in $\mathrm{CHCl}_{3}$ ), Figure $2 \mathrm{a}, \mathrm{b}$. The metallocycle consists of two $\mathrm{Zn}^{2+}$ ions and two ligands. The metal ions have a square pyramidal coordination geometry with a methanol molecule in the apical site. All the $\mathrm{Zn}-\mathrm{O}$ distances, both for equatorial and apical sites, have similar values close to $2 \AA$ (Table 1). The two metal ions are located at a distance of 12.5034(9) $\AA$, while the two methylene carbon atoms of the ligands spacer have a distance of 11.472(5) $\AA$. Compared to its copper analog $\left[\mathrm{Cu}_{2} \mathrm{~L}_{2}\right][9]$, synthesized in the same solvents $(\mathrm{MeOH} / \mathrm{CHCl})_{3}$, the metal ions in $\left[\mathrm{Zn}_{2} \mathrm{~L}_{2}\right]$ have a square pyramidal coordination geometry due to the coordinated methanol, while in $\left[\mathrm{Cu}_{2} \mathrm{~L}_{2}\right]$, the copper centers have a distorted planar-square coordination geometry.

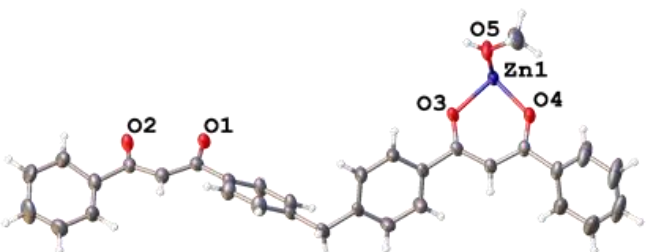

(a)

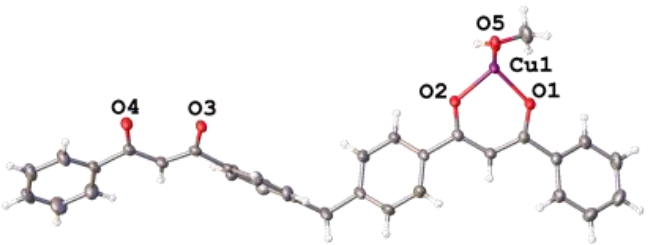

(c)

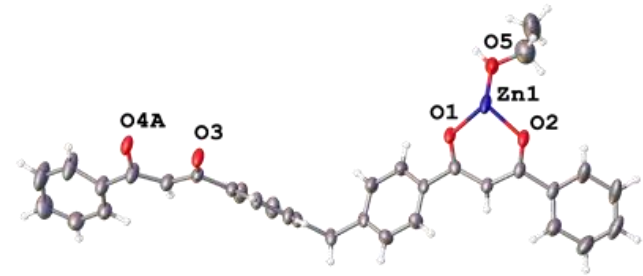

(e)

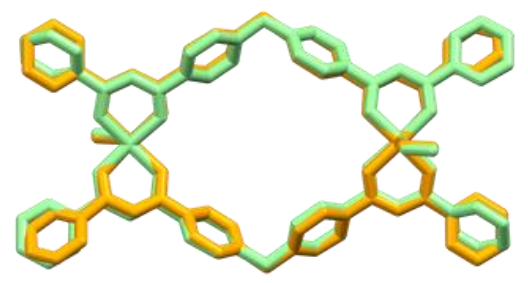

(g)

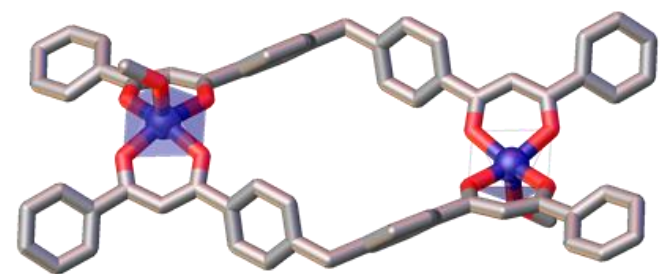

(b)

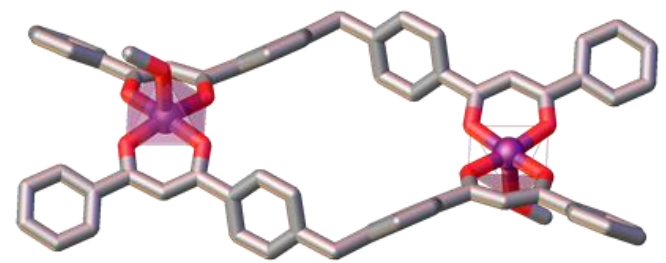

(d)

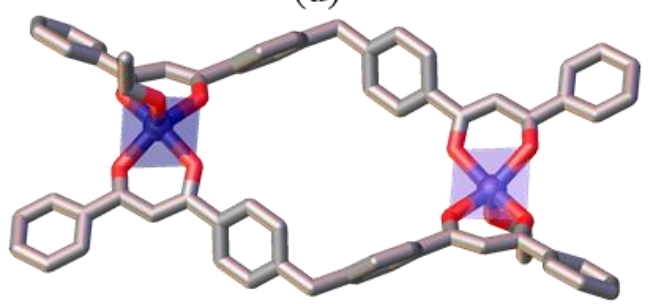

(f)

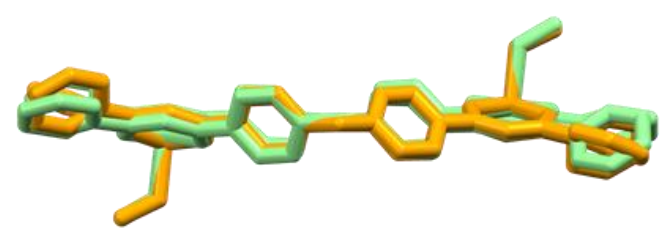

(h)

Figure 2. (a) Asymmetric unit of $\left[\mathrm{Zn}_{2} \mathrm{~L}_{2}(\mathrm{MeOH})_{2}\right]$, 1. (b) Metallocycle $\left[\mathrm{Zn}_{2} \mathrm{~L}_{2}(\mathrm{MeOH})_{2}\right]$, 1. (c) Asymmetric unit of $\left[\mathrm{Cu}_{2} \mathrm{~L}_{2}(\mathrm{MeOH})_{2}\right]$, 2. (d) Metallocycle $\left[\mathrm{Cu}_{2} \mathrm{~L}_{2}(\mathrm{MeOH})_{2}\right]$, 2. (e) Asymmetric unit of $\left[\mathrm{Zn}_{2} \mathrm{~L}_{2}(\mathrm{EtOH})_{2}\right]$, 3. (f) Metallocycle $\left[\mathrm{Zn}_{2} \mathrm{~L}_{2}(\mathrm{EtOH})_{2}\right]$, 3. (g,h) Top and lateral views of the overlapped metallocycles, orange $\mathbf{1}$ and green 2 . Color code: $\mathrm{Zn}$, dark blue; $\mathrm{Cu}$, purple; $\mathrm{O}$, red; $\mathrm{C}$, grey; $\mathrm{H}$, white. Solvent and disordered part omitted for clarity; thermal ellipsoids drawn at the 50\% probability level. 
Table 1. Main distances $(\AA)$ in the discussed metallocycles.

\begin{tabular}{|c|c|c|c|c|}
\hline Bond & {$\left[\mathrm{Zn}_{2} \mathrm{~L}_{2}(\mathrm{MeOH})_{2}\right], 1$} & {$\left[\mathrm{Cu}_{2} \mathrm{~L}_{2}(\mathrm{MeOH})_{2}\right], 2$} & {$\left[\mathrm{Zn}_{2} \mathrm{~L}_{2}(\mathrm{EtOH})_{2}\right], 3$} & {$\left[\mathrm{Zn}_{2} \mathrm{~L}_{2}(\mathrm{py})_{2}\right], 5$} \\
\hline M-O1 & 2.0153(16) & $1.9338(19)$ & 2.0525(16) & $1.9817(13)$ \\
\hline $\mathrm{M}-\mathrm{O} 2$ & $1.9951(16)$ & $1.9404(18)$ & $2.0008(17)$ & $2.0681(12)$ \\
\hline $\mathrm{M}-\mathrm{O} 3$ & $2.0304(16)$ & $1.9430(18)$ & $2.0283(17)$ & $1.9918(13)$ \\
\hline M-O4 & $2.0023(17)$ & $1.9290(19)$ & $2.092(9)$ & $2.0948(12)$ \\
\hline $\mathrm{M}-\mathrm{O} 5(\mathrm{ROH})$ & 2.0213(19) & $2.245(2)$ & $2.008(3)$ & - \\
\hline M-N1 (py) & - & - & - & $2.0608(15)$ \\
\hline $\mathrm{M} \cdots \mathrm{M}$ & $12.5034(9)$ & $12.4735(14)$ & $12.5255(7)$ & $12.8868(5)$ \\
\hline$C \cdots C^{1}$ & $11.472(5)$ & $11.269(6)$ & $11.481(4)$ & $11.011(3)$ \\
\hline
\end{tabular}

$\mathrm{M}=\mathrm{Zn} 1$ or $\mathrm{Cu1} ;{ }^{1}$ central methylene $\mathrm{C}$ atom of the ligand.

By changing the synthetic conditions, we were able to isolate a similar copper-based compound $\left\{\left[\mathrm{Cu}_{2} \mathrm{~L}_{2}(\mathrm{MeOH})_{2}\right] \cdot 2\left(\mathrm{CH}_{2} \mathrm{Cl}_{2}\right)\right\}, 2$ (Figure $2 \mathrm{c}, \mathrm{d}$ ), where the $\mathrm{Cu}^{2+}$ ions have a square pyramidal coordination geometry very close to that of $\left[\mathrm{Zn}_{2} \mathrm{~L}_{2}(\mathrm{MeOH})_{2}\right]$ (Table 1 for main distances). The two crystal structures are not isostructural, but the copper and zinc metallocycles have very similar dimensions and shape as evidenced by their overlapping, Figure $2 \mathrm{~g}, \mathrm{~h}$. A deeper analysis of the crystal packing of $\left[\mathrm{Zn}_{2} \mathrm{~L}_{2}(\mathrm{MeOH})_{2}\right]$ and $\left[\mathrm{Cu}_{2} \mathrm{~L}_{2}(\mathrm{MeOH})_{2}\right]$ highlighted that in both cases the coordinated methanol molecules of a metallocycle are partially hosted in the cavity of other metallocycles. These molecules interact with the hosting metallocycle through a bifurcated $\mathrm{H}$-bond (Table 2) between the methanol $\mathrm{OH}$ group and the two oxygen atoms of the ligands facing the inside of the metallocycle cavity, Figure 3a. This leads to the formation of a supramolecular H-bond-supported 1D polymer (Figure 3b), where each metallocycle pocket hosts two methanol molecules.

Table 2. H-bond lengths $(\AA)$ and angles $(\angle)$.

\begin{tabular}{|c|c|c|}
\hline$\left[\mathrm{Zn}_{2} \mathrm{~L}_{2}(\mathrm{MeOH})_{2}\right], 1$ & {$\left[\mathrm{Cu}_{2} \mathrm{~L}_{2}(\mathrm{MeOH})_{2}\right], 2$} & {$\left[\mathrm{Zn}_{2} \mathrm{~L}_{2}(\mathrm{EtOH})_{2}\right], 3$} \\
\hline $\mathrm{d}(\mathrm{O} 5 \mathrm{H} \cdots \mathrm{O} 3)=2.136(18) \AA$ & $\mathrm{d}(\mathrm{O} 5 \mathrm{H} \cdots \mathrm{O} 3)=2.0784(2) \AA$ & $\mathrm{d}(\mathrm{O} 5 \mathrm{H} \cdots \mathrm{O} 1)=1.959(12) \AA$ \\
\hline$\angle(\mathrm{O} 5 \mathrm{H} \cdots \mathrm{O} 3)=144.707(4)^{\circ}$ & $\angle(\mathrm{O} 5 \mathrm{H} \cdots \mathrm{O} 3)=164.085(3)^{\circ}$ & $\angle(\mathrm{O} 5 \mathrm{H} \cdots \mathrm{O} 1)=162.41(2)^{\circ}$ \\
\hline $\mathrm{d}(\mathrm{O} 5 \mathrm{H} \cdots \mathrm{O} 1)=2.281(5) \AA$ & $\mathrm{d}(\mathrm{O} 5 \mathrm{H} \cdots \mathrm{O} 2)=2.5744(3) \AA$ & \\
\hline$\angle(\mathrm{O} 5 \mathrm{H} \cdots \mathrm{O} 1)=133.308(4)^{\circ}$ & $\angle(\mathrm{O} 5 \mathrm{H} \cdots \mathrm{O} 2)=121.359(8)^{\circ}$ & \\
\hline
\end{tabular}

Metallocycle $\left[\mathrm{Zn}_{2} \mathrm{~L}_{2}\right]$ was also prepared by employing other alcohols, such as ethanol $(\mathrm{EtOH})$ and 2-propanol (iPrOH). When bulkier alcohols were used (i.e., 1-butanol and 2-butanol), we did not isolate any compound. In the case of $\mathrm{EtOH}$, the structure was characterized by single crystal X-ray diffraction (SCXRD). The metallocycle $\left\{\left[\mathrm{Zn}_{2} \mathrm{~L}_{2}(\mathrm{EtOH})_{2}\right] \cdot 2\left(\mathrm{CHCl}_{3}\right)\right\}, 3$ (Figure 2e,f), crystallizes with the same unit cell of compound $\mathbf{1}$ (Table 3 ) and it shows the same supramolecular packing evidenced by compounds $\mathbf{1}$ and $\mathbf{2}$. The coordinated ethanol molecules of a metallocycle thread the cavity of other metallocycles, forming an H-bond (Table 2) with the hosting metallocycle. It is worthy to add that the terminal methyl group of the EtOH molecule is disordered over two different positions and this leads to two different orientations for the $\mathrm{EtOH}$ molecule. In the first, the molecule completely threads the cavity of a second metallocycle, while in the second one EtOH is only partially hosted by the cavity (Figure S1). In the case of the compound synthesized with isopropanol, we did not succeed in obtaining single crystals suitable for SCXRD. Only microcrystalline materials were obtained. Powder X-ray diffraction (PXRD) revealed a pattern extremely similar to those of compounds $\mathbf{1}$ and 3, Figure S2. An indexing of the PXRD pattern (Figure S3) allowed determining the unit cell leading to values similar to metallocycles 1 and 3 (Table S1). Moreover, elemental analyses confirmed the presence of two isopropanol molecules in each metallocycle according to the formula $\left[\mathrm{Zn}_{2} \mathrm{~L}_{2}(i \mathrm{PrOH})_{2}\right]$. All these evidences strongly support the conclusion that $\left[\mathrm{Zn}_{2} \mathrm{~L}_{2}(i \mathrm{PrOH})_{2}\right]$ also has the previously described supramolecular packing, with the alcohol molecules of a metallocycle hosted in the cavities of other rings. 


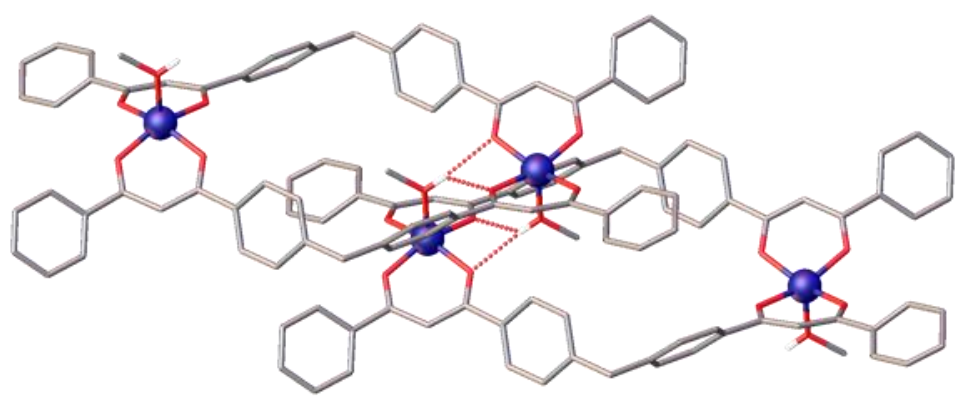

(a)

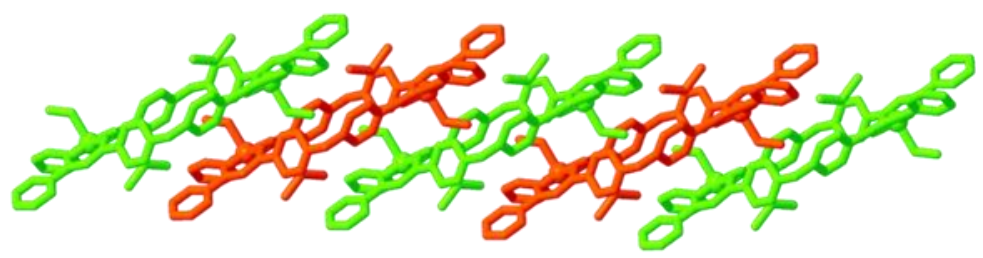

(b)

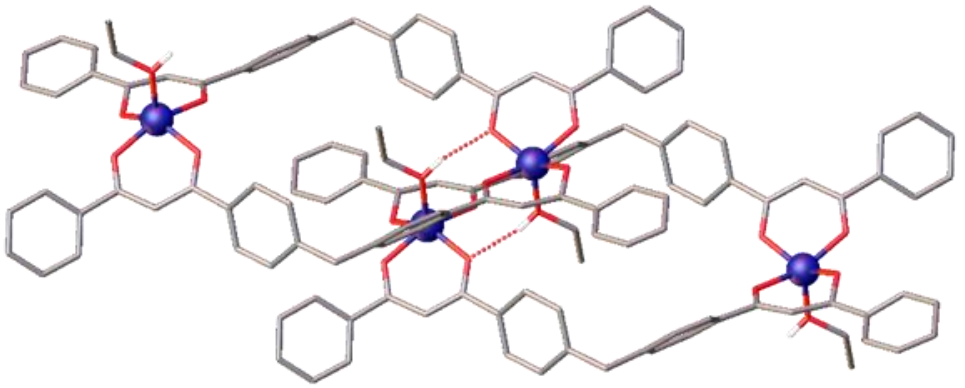

(c)

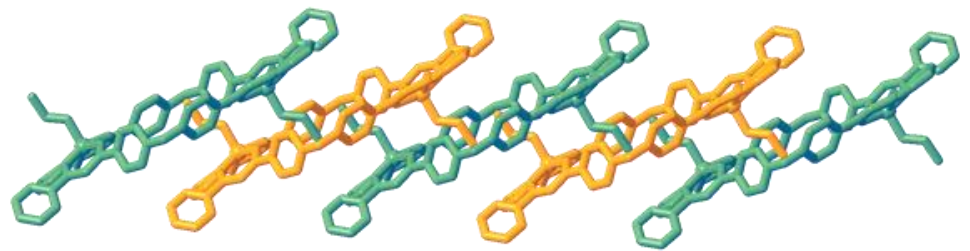

(d)

Figure 3. (a) H-bonds between two $\left[\mathrm{Zn}_{2} \mathrm{~L}_{2}(\mathrm{MeOH})_{2}\right]$ metallocycles (H-bond: dotted red line). (b) $\mathrm{H}$-bond-supported $1 \mathrm{D}$ polymer in 1. (c) $\mathrm{H}$-bonds between two $\left[\mathrm{Zn}_{2} \mathrm{~L}_{2}(\mathrm{EtOH})_{2}\right]$ metallocycles $(\mathrm{H}-$ bond: dotted red line). (d) H-bond-supported 1D polymer in 3. Color code: Zn, dark blue; O, red; C, grey; $\mathrm{H}$, white.

Table 3. Crystal data and structure refinement details.

\begin{tabular}{ccccc}
\hline Compound & $\mathbf{1}$ & $\mathbf{2}$ & $\mathbf{3}$ & $\mathbf{5}$ \\
\hline Formula & $\mathrm{C}_{66} \mathrm{H}_{54} \mathrm{O}_{10} \mathrm{Cl}_{6} \mathrm{Zn}_{2}$ & $\mathrm{C}_{66} \mathrm{H}_{56} \mathrm{Cl}_{4} \mathrm{O}_{10} \mathrm{Cu}_{2}$ & $\mathrm{C}_{68} \mathrm{H}_{58} \mathrm{O}_{10} \mathrm{Cl}_{6} \mathrm{Zn}_{2}$ & $\mathrm{C}_{74} \mathrm{H}_{56} \mathrm{Cl}_{6} \mathrm{~N}_{2} \mathrm{O}_{8} \mathrm{Zn}_{2}$ \\
Formula weight & 1111.79 & 1277.98 & 1139.84 & 1444.64 \\
Temperature/K & $143(1)$ & $139.9(2)$ & $150.1(2)$ & $143(1)$ \\
Crystal system & triclinic & triclinic & triclinic & triclinic \\
Space group & $\mathrm{P}-1$ & $\mathrm{P}-1$ & $\mathrm{P}-1$ & $\mathrm{P}-1$ \\
$\boldsymbol{a} / \AA$ & $9.9444(5)$ & $10.1048(9)$ & $9.9945(3)$ & $8.8428(2)$ \\
$\boldsymbol{b} / \AA$ & $12.9319(6)$ & $12.9002(11)$ & $12.8141(3)$ & $12.4056(3)$ \\
$\boldsymbol{c} / \AA$ & $13.6843(7)$ & $13.1829(12)$ & $13.8744(4)$ & $15.8865(4)$ \\
$\boldsymbol{\alpha} /^{\circ}$ & $99.295(4)$ & $67.018(9)$ & $98.971(2)$ & $88.908(2)$ \\
$\boldsymbol{\beta} /^{\circ}$ & $104.338(4)$ & $76.573(8)$ & $105.037(3)$ & $79.215(2)$ \\
$\gamma / /^{\circ}$ & $111.088(5)$ & $67.713(8)$ & $110.495(2)$ & $74.360(2)$ \\
$\mathrm{Z}$ & $1528.45(14)$ & $1456.7(3)$ & $1546.47(8)$ & 1 \\
\end{tabular}


Table 3. Cont.

\begin{tabular}{|c|c|c|c|c|}
\hline Compound & 1 & 2 & 3 & 5 \\
\hline Crystal size $/ \mathrm{mm}^{3}$ & $0.41 \times 0.23 \times 0.13$ & $0.3 \times 0.15 \times 0.02$ & $0.35 \times 0.31 \times 0.25$ & $0.38 \times 0.22 \times 0.1$ \\
\hline Radiation & $\operatorname{MoK} \alpha(\lambda=0.71073)$ & $\operatorname{MoK} \alpha(\lambda=0.71073)$ & $\operatorname{MoK} \alpha(\lambda=0.71073)$ & $\operatorname{MoK} \alpha(\lambda=0.71073)$ \\
\hline $2 \theta$ range for data collection $/^{\circ}$ & $4.654-58.706$ & $4.698-52.744$ & $4.526-58.502$ & $4.872-58.766$ \\
\hline \multirow[t]{2}{*}{ Reflections collected } & 24600 & 11109 & 19517 & 28460 \\
\hline & 7322 & 5954 & 7268 & 7994 \\
\hline Independent reflections & $\begin{array}{c}{\left[\mathrm{R}_{\mathrm{int}}=0.0330,\right.} \\
\left.\mathrm{R}_{\text {sigma }}=0.0349\right]\end{array}$ & $\begin{array}{c}{\left[\mathrm{R}_{\text {int }}=0.0368,\right.} \\
\left.\mathrm{R}_{\text {sigma }}=0.0587\right]\end{array}$ & $\begin{array}{c}{\left[\mathrm{R}_{\text {int }}=0.0200,\right.} \\
\left.\mathrm{R}_{\text {sigma }}=0.0248\right]\end{array}$ & $\begin{aligned} {\left[\mathrm{R}_{\text {int }}\right.} & =0.0305, \\
\mathrm{R}_{\text {sigma }} & =0.0285]\end{aligned}$ \\
\hline Data/restraints/parameters & $7322 / 339 / 384$ & $5954 / 3 / 374$ & $7268 / 18 / 408$ & $7994 / 0 / 415$ \\
\hline Goodness-of-fit on $\mathrm{F}^{2}$ & 1.031 & 1.027 & 1.037 & 1.029 \\
\hline $\begin{array}{l}\text { Final } R \text { indexes } \\
{[I \geq 2 \sigma(I)]}\end{array}$ & $\begin{array}{c}\mathrm{R}_{1}=0.0465 \\
\mathrm{wR}_{2}=0.1176\end{array}$ & $\begin{array}{c}\mathrm{R}_{1}=0.0460 \\
\mathrm{wR}_{2}=0.1092\end{array}$ & $\begin{array}{c}\mathrm{R} 1=0.0483 \\
\mathrm{wR} 2=0.1308\end{array}$ & $\begin{array}{r}\mathrm{R}_{1}=0.0359 \\
w R_{2}=0.0883\end{array}$ \\
\hline Final R indexes [all data] & $\begin{array}{r}\mathrm{R}_{1}=0.0585 \\
\mathrm{wR}_{2}=0.1263\end{array}$ & $\begin{array}{r}\mathrm{R}_{1}=0.0610 \\
\mathrm{wR}_{2}=0.1202\end{array}$ & $\begin{array}{r}\mathrm{R} 1=0.0624 \\
\mathrm{wR} 2=0.1424\end{array}$ & $\begin{array}{r}\mathrm{R}_{1}=0.0428 \\
\mathrm{wR}_{2}=0.0931\end{array}$ \\
\hline Largest diff. peak/hole/e $\AA^{-3}$ & $1.80 /-0.58$ & $0.45 /-0.56$ & $1.16 /-0.88$ & $0.71 /-0.61$ \\
\hline CCDC & 1955909 & 1955907 & 1964015 & 1955908 \\
\hline
\end{tabular}

Crystal structures of the $\left[\mathrm{Zn}_{2} \mathrm{~L}_{2}(\mathrm{ROH})_{2}\right]$ systems $(\mathrm{ROH}=\mathrm{MeOH}$ and $\mathrm{EtOH})$ confirmed that $\left[\mathrm{Zn}_{2} \mathrm{~L}_{2}\right]$ has the desired features to act as a platform for the formation of polyrotaxanes via coordination and supramolecular tools: (i) a pocket with hosting properties and (ii) the ability to coordinate other species. Moreover, the similarity between the structures of $\left[\mathrm{Cu}_{2} \mathrm{~L}_{2}(\mathrm{MeOH})_{2}\right]$ and $\left[\mathrm{Zn}_{2} \mathrm{~L}_{2}(\mathrm{MeOH})_{2}\right]$ strongly suggested that the $\mathrm{Zn}$-based metallocycle may also be used as a platform to self-assemble polyrotaxane architectures. Hence, we reacted $\left[\mathrm{Zn}_{2} \mathrm{~L}_{2}(\mathrm{MeOH})_{2}\right]$ with two similar ancillary ligands: pyridine (py) and $4,4^{\prime}$-bipyridine (bipy). In our previous work [9], we demonstrated that bipy coupled to the $\left[\mathrm{Cu}_{2} \mathrm{~L}_{2}\right]$ metallocycle can lead to interpenetrated polyrotaxane-like extended architectures, with bipy bridging two different metallocycles and at the same time threading a third metallocycle, Figure $1 \mathrm{~b}$. The reaction between $\left[\mathrm{Zn}_{2} \mathrm{~L}_{2}\right]$ and bipy led to the immediate formation of an insoluble product. Elemental analyses suggested the formation of the coordination polymer of formula $\left[\mathrm{Zn}_{2} \mathrm{~L}_{2}(\text { bipy })\right]_{n}$. Despite several efforts, we were not able to isolate single crystals. An indexing of the PXRD pattern of $\left[\mathrm{Zn}_{2} \mathrm{~L}_{2} \text { (bipy) }\right]_{n}$ led to a unit cell different from that of $\left[\mathrm{Cu}_{2} \mathrm{~L}_{2} \text { (bipy) }\right]_{n}$ (Figures S4 and S5, Table S2). Hence, we cannot confirm the formation of an interpenetrated structure. On the contrary, the reaction between py and $\left[\mathrm{Zn}_{2} \mathrm{~L}_{2}\right]$ allowed the isolation of light yellow single crystals of $\left\{\left[\mathrm{Zn}_{2} \mathrm{~L}_{2}(\mathrm{py})_{2}\right] \cdot 2\left(\mathrm{CHCl}_{3}\right)\right\}$. Single crystals were obtained in high yield $(80 \%$ ca.) from a chloroform solution of $\mathrm{L}$ and py layered with a methanol solution of $\mathrm{Zn}\left(\mathrm{CH}_{3} \mathrm{COO}\right)_{2}$ in order to induce crystallization by the reactants diffusion technique. In $\left[\mathrm{Zn}_{2} \mathrm{~L}_{2}(\mathrm{py})_{2}\right], 5$, the zinc ions have a pyridine molecule coordinated in the apical position of a distorted square pyramid and the $\beta$-diketonate oxygen atoms in the equatorial position with distances close to $2 \AA$ (Figure $4 \mathrm{a}, \mathrm{b}$; Table 1 for main distances) as found in the cases of $\left[\mathrm{Zn}_{2} \mathrm{~L}_{2}(\mathrm{MeOH})_{2}\right]$ and $\left[\mathrm{Zn}_{2} \mathrm{~L}_{2}(\mathrm{EtOH})_{2}\right]$. When MeOH molecules were substituted with pyridine, metallocycle dimensions did not change significantly (Table 1). The analysis of the supramolecular packing showed that pyridine molecules of two different metallocycles interact via $\pi \cdots \pi$ stacking to form supramolecular 1D chains. Moreover, the pyridine molecule of a ring threads the cavity of another one in a manner similar to that observed for alcohol molecules. Each metallocycle hosts two pyridine molecules (Figure $4 \mathrm{c}$ ) and these two guests are involved in $\pi \cdots \pi$ stacking. The interaction between the two pyridine molecules can be described as a parallel-displaced stacking (also referred to as parallel off-centered or slipped stacking), Figure $4 \mathrm{~d}-\mathrm{e}$. This is the more usual conformation displayed by aromatic-nitrogen-containing ligands [20]. Moreover, it is well known that the coordination to a metal ion of the nitrogen atom further improves the stacking due to a higher polarization [20]. Figure 4e highlights the most important geometric parameters of the two interacting pyridine molecules. The distances between the pyridine planes and pyridine centroids $(\mathrm{Cg})$ are in agreement with the values usually found for a coordinated pyridine [20], leading to $\mathrm{C} \cdots \mathrm{C}$ and $\mathrm{C}-\mathrm{H} \cdots \mathrm{Cg}$ distances of 3.34 and $3.38 \AA$, respectively. Stacking among aromatic-nitrogen-containing ligands can strongly influence compound properties, such as luminescence [21], conductivity [22], metal uptake [23], and structural features [24], leading to interdigitated and interlocked architectures [25]. In the case of the $\left[\mathrm{Zn}_{2} \mathrm{~L}_{2}(\mathrm{py})_{2}\right]$ metallocycle, stacking interactions lead 
to a complex supramolecular arrangement, where pairs of 1D chains entangle, with each metallocycle of one chain threaded by a py *.py axle of the other chain, establishing a 1D $+1 \mathrm{D} \rightarrow 1 \mathrm{D}$ supramolecular polyrotaxane supported by $\pi \cdots \pi$ stacking between ancillary ligands. This interpenetrated topology is very rare. Indeed, six examples of $1 \mathrm{D}+1 \mathrm{D} \rightarrow 1 \mathrm{D}$ polyrotaxane-based on metallocycle rings have been reported so far [9,26-31]. However, only for the coordination-driven $\left[\mathrm{Cu}_{2} \mathrm{~L}_{2}(\text { bipy })\right]_{n}$ discussed above [9] and the $\pi \cdots \pi$ stacking-supported polyrotaxane here presented, the extended network is based on a metallocycle $\left[\mathrm{M}_{2} \mathrm{~L}_{2}\right]\left(\mathrm{M}=\mathrm{Cu}^{2+}\right.$ and $\left.\mathrm{Zn}^{2+}\right)$ that exists in solution as a discrete unit and that can act as a platform for the reversible self-assembly of the intertwined structure [9].

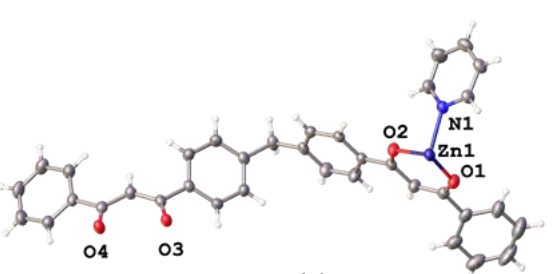

(a)

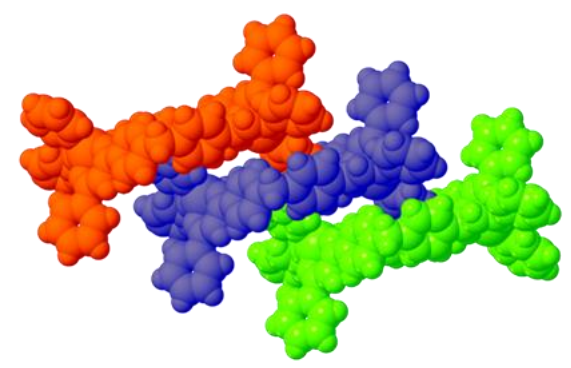

(c)

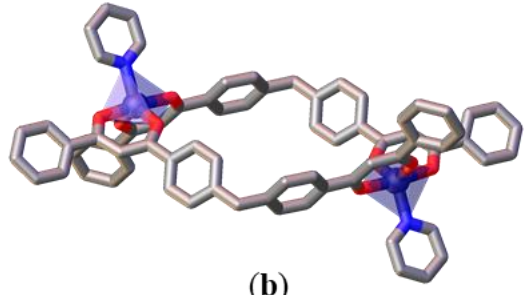

(b)

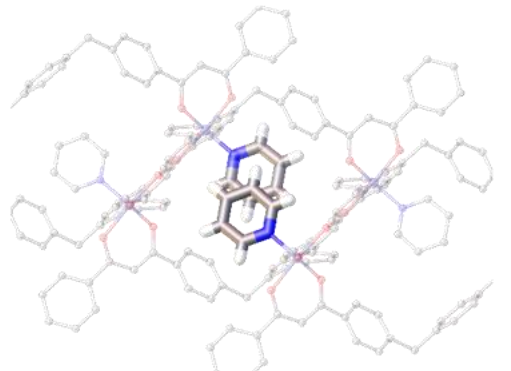

(d)

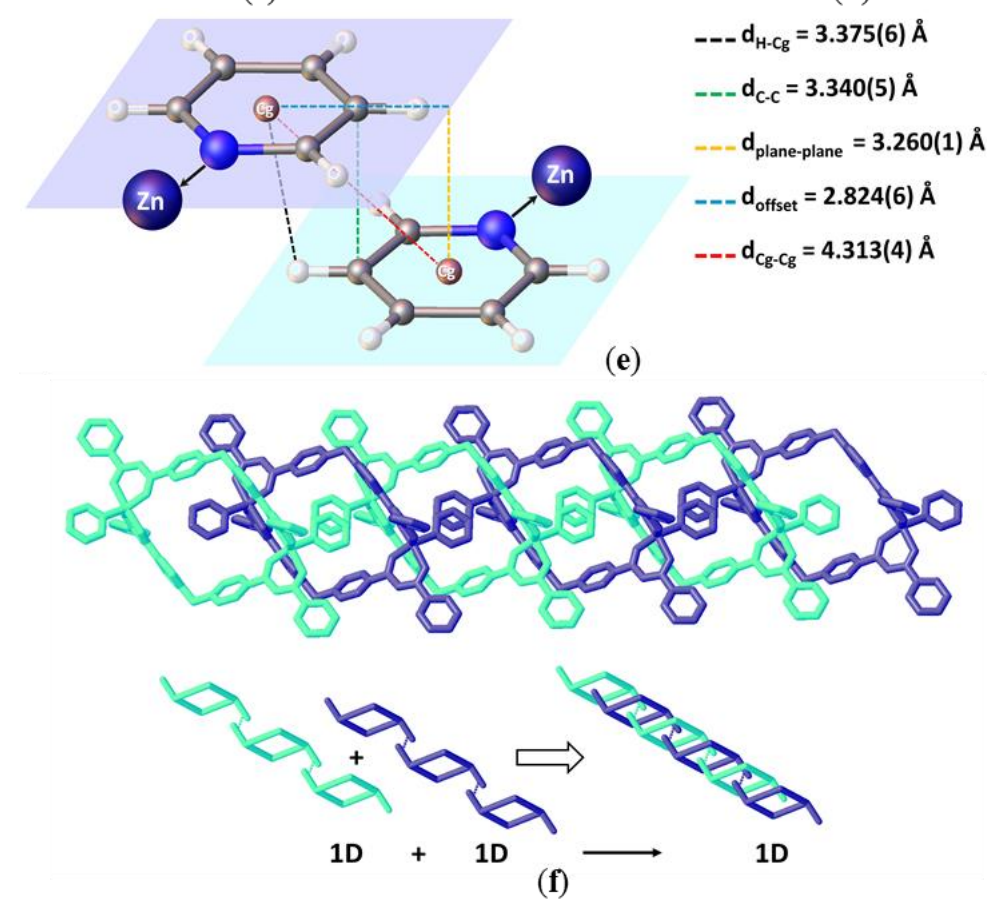

(f)

Figure 4. (a,b) Asymmetric unit and metallocycle $\left[\mathrm{Zn}_{2} \mathrm{~L}_{2}(\mathrm{py})_{2}\right]$, 5. (c,d) Stacking interactions between pyridine molecules of two metallocycles inside the cavity of a third metallocycle. (e) Geometric parameters of the $\pi \cdots \pi$ stacking. (f) The intertwined 1D supramolecular chain and a schematic representation of the self-assembly of the $1 \mathrm{D}+1 \mathrm{D} \rightarrow 1 \mathrm{D}$ polyrotaxane topology supported by $\pi \cdots \pi$ stacking between two 1D chains (turquoise and blue). Color code: $\mathrm{Zn}$, dark blue; $\mathrm{O}$, red; $\mathrm{N}$, light blue; $\mathrm{C}$, grey; $\mathrm{H}$, white; centroid $(\mathrm{Cg})$, bronze. Solvent omitted for clarity; thermal ellipsoids drawn at the $50 \%$ probability level. 


\section{Materials and Methods}

\subsection{Synthesis}

The reagents were purchased from Sigma-Aldrich (St. Louis, MO, USA) and used as received. The ligand L was prepared as previously reported [9]. The elemental analyses were carried out with a Flash 2000 Thermo Scientific analyzer (Thermo Fisher Scientific, Cambridge, UK) at the Department of Chemical Sciences of the University of Padova.

\subsubsection{Synthesis of $\left\{\left[\mathrm{Zn}_{2} \mathrm{~L}_{2}(\mathrm{MeOH})_{2}\right] \cdot 2 \mathrm{CHCl}_{3}\right\}(\mathbf{1})$}

Single crystals of $\left\{\left[\mathrm{Zn}_{2} \mathrm{~L}_{2}(\mathrm{MeOH})_{2}\right] \cdot 2 \mathrm{CHCl}_{3}\right\}$ were obtained via reactant diffusion. A chloroform solution $(15 \mathrm{~mL})$ of $\mathrm{L}(46.1 \mathrm{mg}, 0.1 \mathrm{mmol})$ was layered with a methanol solution $(15 \mathrm{~mL})$ of $\mathrm{Zn}\left(\mathrm{CH}_{3} \mathrm{COO}\right)_{2} \cdot 2 \mathrm{H}_{2} \mathrm{O}(22.0 \mathrm{mg}, 0.1 \mathrm{mmol})$. The vial was stoppered and the solutions were allowed to diffuse slowly. After a few days, needle-shaped colorless crystals suitable for X-ray analysis were obtained. By reducing the solvent volume, more crystals were obtained. Yield $115 \mathrm{mg}$, 85\%. The elemental analysis for $\mathrm{C}_{66} \mathrm{H}_{54} \mathrm{Cl}_{6} \mathrm{Zn}_{2} \mathrm{O}_{10}$, $\exp (\%)$ : C 59.01, $\mathrm{H} 4.15$; calc (\%): C 58.69, $\mathrm{H} 4.03$.

\subsubsection{Synthesis of $\left\{\left[\mathrm{Cu}_{2} \mathrm{~L}_{2}(\mathrm{MeOH})_{2}\right] \cdot 2 \mathrm{CH}_{2} \mathrm{Cl}_{2}\right\}$ (2)}

Blade-like single crystals of $\left\{\left[\mathrm{Cu}_{2} \mathrm{~L}_{2}(\mathrm{MeOH})_{2}\right] \cdot 2 \mathrm{CH}_{2} \mathrm{Cl}_{2}\right\}$ were obtained via reactant diffusion. A $\mathrm{CH}_{2} \mathrm{Cl}_{2}$ solution $(4 \mathrm{~mL})$ of $\mathrm{L}(11.5 \mathrm{mg}, 0.025 \mathrm{mmol})$ was layered with a methanol solution $(4 \mathrm{~mL})$ of $\mathrm{Cu}\left(\mathrm{CH}_{3} \mathrm{COO}\right)_{2} \cdot \mathrm{H}_{2} \mathrm{O}(5 \mathrm{mg}, 0.025 \mathrm{mmol})$. The vial was stoppered and the solutions were allowed to diffuse slowly. After a few days, light blue single crystals suitable for $\mathrm{X}$-ray analysis were obtained. Yield $12 \mathrm{mg}$, 72\%. The elemental analysis for $\mathrm{C}_{68} \mathrm{H}_{56} \mathrm{Cl}_{4} \mathrm{Cu}_{2} \mathrm{O}_{10}$, exp (\%): C 62.51, $\mathrm{H} 4.25$; calc (\%): C $62.73, \mathrm{H} 4.33$.

\subsubsection{Synthesis of $\left\{\left[\mathrm{Zn}_{2} \mathrm{~L}_{2}(\mathrm{EtOH})_{2}\right] \cdot 2 \mathrm{CHCl}_{3}\right\}$ (3)}

Single crystals of $\left\{\left[\mathrm{Zn}_{2} \mathrm{~L}_{2}(\mathrm{EtOH})_{2}\right] \cdot 2 \mathrm{CHCl}_{3}\right\}$ were obtained via reactant diffusion. A chloroform solution $(15 \mathrm{~mL})$ of $\mathrm{L}(46.0 \mathrm{mg}, 0.1 \mathrm{mmol})$ was layered with an ethanol solution $(15 \mathrm{~mL})$ of $\mathrm{Zn}\left(\mathrm{CH}_{3} \mathrm{COO}\right)_{2} \cdot 2 \mathrm{H}_{2} \mathrm{O}(22.1 \mathrm{mg}, 0.1 \mathrm{mmol})$. The vial was stoppered and the solutions were allowed to diffuse slowly. After a few days, colorless crystals suitable for X-ray analysis were obtained. By reducing the solvent volume, more crystals were obtained. Yield $109 \mathrm{mg}, 79 \%$. The elemental analysis for $\mathrm{C}_{68} \mathrm{H}_{58} \mathrm{Cl}_{6} \mathrm{Zn}_{2} \mathrm{O}_{10}$, exp (\%): C 59.32, $\mathrm{H} 4.21$; calc (\%): C 59.24, $\mathrm{H} 4.24$.

\subsubsection{Synthesis of $\left[\mathrm{Zn}_{2} \mathrm{~L}_{2}(i \mathrm{PrOH})_{2}\right](4)$}

A microcrystalline powder of $\left[\mathrm{Zn}_{2} \mathrm{~L}_{2}(i \mathrm{PrOH})_{2}\right]$ were obtained via reactant diffusion. A chloroform solution $(15 \mathrm{~mL})$ of $\mathrm{L}(46.2 \mathrm{mg}, 0.1 \mathrm{mmol})$ was layered with an isopropanol solution $(15 \mathrm{~mL})$ of $\mathrm{Zn}\left(\mathrm{CH}_{3} \mathrm{COO}\right)_{2} \cdot 2 \mathrm{H}_{2} \mathrm{O}(22.1 \mathrm{mg}, 0.1 \mathrm{mmol})$. The vial was stoppered and the solutions were allowed to diffuse slowly. After a few days, needle-shaped colorless crystals suitable for X-ray analysis were obtained. By reducing the solvent volume, more crystals were obtained. Yield $100 \mathrm{mg}, 85 \%$. The elemental analysis for $\mathrm{C}_{68} \mathrm{H}_{60} \mathrm{Zn}_{2} \mathrm{O}_{10}$, $\exp (\%)$ : C 70.05, H 5.23; calc (\%): C 69.93, H 5.18.

\subsubsection{Synthesis of $\left\{\left[\mathrm{Zn}_{2} \mathrm{~L}_{2}\right](\mathrm{py})_{2} \cdot 2 \mathrm{CHCl}_{3}\right\}(5)$}

A chloroform solution ( $5 \mathrm{~mL}$ ) of ligand $(55.48 \mathrm{mg}, 0.125 \mathrm{mmol})$ and pyridine $(62.5 \mu \mathrm{l}, 0.75 \mathrm{mmol})$ was layered with a methanol solution $(5 \mathrm{~mL})$ of $\mathrm{Zn}\left(\mathrm{CH}_{3} \mathrm{COO}\right)_{2} \cdot 2 \mathrm{H}_{2} \mathrm{O}(28 \mathrm{mg}, 0.125 \mathrm{mmol})$. The vial was stoppered and the solutions were allowed to diffuse slowly. After a few days, irregular-shaped colorless crystals suitable for X-ray analysis were obtained. Yield $115 \mathrm{mg}, 80 \%$. The elemental analysis for $\mathrm{C}_{74} \mathrm{H}_{56} \mathrm{Cl}_{6} \mathrm{Zn}_{2} \mathrm{~N}_{2} \mathrm{O}_{10}$, exp (\%): C 61.95, N 2.05, H 4.02; calc (\%): C 61.52, N 1.94, H 3.91. 


\subsection{Crystal Structure Determination}

Data were collected with an Oxford Diffraction Gemini E diffractometer (Oxford Diffraction, Oxfordshire, England), equipped with a $2 \mathrm{~K} \times 2 \mathrm{~K}$ EOS CCD area detector and sealed-tube enhance $(\mathrm{Mo})$ and $(\mathrm{Cu}) \mathrm{X}$-ray sources. Details of data collections, structures solution, and refinement are given as Supplementary Materials. Crystallographic Information Files (CIF) have been deposited at the Cambridge Crystallographic Data Centre as supplementary publication (CCDC 1942113-1942116, 1964015).

\section{Conclusions}

In conclusion, we have reported how a discrete Zn-based metallocycle can be exploited as a platform to self-assemble intertwined polyrotaxane-like architectures by using an ancillary ligand that coordinates the metallocycle. The proposed approach builds up entangled structures starting from metallocycles and projects a system with two main features (i) metal centers capable of expanding their coordination sphere and (ii) host-guest properties. The results reported here for the $\left[\mathrm{Zn}_{2} \mathrm{~L}_{2}\right]$ metallocycle, coupled with the previous studies for its $\left[\mathrm{Cu}_{2} \mathrm{~L}_{2}\right]$ analog [9], show that such metallorings are particularly suited as platforms to develop $1 \mathrm{D}+1 \mathrm{D} \rightarrow 1 \mathrm{D}$ polyrotaxane architectures driven either through ancillary bridging ligands (bipy) or ancillary ligands that can give $\pi \cdots \pi$ stacking (py).

Supplementary Materials: The following are available online at http://www.mdpi.com/2304-6740/7/11/137/s1, XRD details, experimental and additional structural figures; CIF and checkCIF files of the crystal structures; $\left[\mathrm{Zn}_{2} \mathrm{~L}_{2}(\mathrm{MeOH})_{2}\right],\left[\mathrm{Zn}_{2} \mathrm{~L}_{2}(\mathrm{EtOH})_{2}\right]$, and $\left[\mathrm{Zn}_{2} \mathrm{~L}_{2}(i \mathrm{PrOH})_{2}\right]$ PXRD patterns; $\left[\mathrm{Zn}_{2} \mathrm{~L}_{2}(\text { bipy })\right]_{n}$ synthesis and PXRD pattern.

Author Contributions: Conceptualization, M.R.; validation, M.R. and L.A.; investigation, G.T., A.C. and M.R; writing-original draft preparation, M.R.; writing-review and editing, all authors; funding acquisition, M.R. and L.A.

Funding: This research was funded by the University of Padova (grant: P-DISC \#CARL-SID17 BIRD2017-UNIPD), project CHIRoN.

Conflicts of Interest: The authors declare no conflicts of interest. The funders had no role in the design of the study; in the collection, analyses, or interpretation of data; in the writing of the manuscript; or in the decision to publish the results.

\section{References}

1. Bruns, C.J.; Stoddart, J.F. The Nature of the Mechanical Bond: From Molecules to Machines; John Wiley \& Sons, Inc.: Hoboken, NJ, USA, 2016; ISBN 9781119044123.

2. Fujita, M.; Ibukuro, F.; Hagihara, H.; Ogura, K. Quantitative self-assembly of a [2]catenane from two preformed molecular rings. Nature 1994, 367, 720-723. [CrossRef]

3. Fujita, M.; Fujita, N.; Ogura, K.; Yamaguchi, K. Spontaneous assembly of ten components into two interlocked, identical coordination cages. Nature 1999, 400, 52-55. [CrossRef]

4. Frank, M.; Johnstone, M.D.; Clever, G.H. Interpenetrated Cage Structures. Chem. Eur. J. 2016, 22, 14104-14125. [CrossRef] [PubMed]

5. Fernandez, A.; Ferrando-Soria, J.; Pineda, E.M.; Tuna, F.; Vitorica-Yrezabal, I.J.; Knappke, C.; Ujma, J.; Muryn, C.A.; Timco, G.A.; Barran, P.E.; et al. Making hybrid [ $n$ ]-rotaxanes as supramolecular arrays of molecular electron spin qubits. Nat. Commun. 2016, 7, 10240. [CrossRef]

6. Lee, C.F.; Leigh, D.A.; Pritchard, R.G.; Schultz, D.; Teat, S.J.; Timco, G.A.; Winpenny, R.E.P. Hybrid organic-inorganic rotaxanes and molecular shuttles. Nature 2009, 458, 314-318. [CrossRef]

7. Fernandez, A.; Moreno Pineda, E.; Ferrando-Soria, J.; McInnes, E.J.L.; Timco, G.A.; Winpenny, R.E.P. A hybrid organic-inorganic molecular daisy chain. Chem. Commun. 2015, 51, 11126-11129. [CrossRef]

8. Jiang, L.; Ju, P.; Meng, X.R.; Kuang, X.J.; Lu, T.B. Constructions of two polycatenanes and one polypseudo-rotaxane by discrete tetrahedral cages and stool-like building units. Sci. Rep. 2012, 2, 668. [CrossRef] 
9. Truccolo, G.; Tessari, Z.; Tessarolo, J.; Quici, S.; Armelao, L.; Rancan, M. A Cu(II) metallocycle for the reversible self-assembly of coordination-driven polyrotaxane-like architectures. Dalton Trans. 2018, 47, 12079-12084. [CrossRef]

10. Ju, H.; Clegg, J.K.; Park, K.M.; Lindoy, L.F.; Lee, S.S. Formation of a Dicopper Platform Based Polyrotaxane Whose "String" and "Bead" Are Constructed from the Same Components. J. Am. Chem. Soc. 2015, 137, 9535-9538. [CrossRef]

11. Whitehead, G.F.S.; Cross, B.; Carthy, L.; Milway, V.A.; Rath, H.; Fernandez, A.; Heath, S.L.; Muryn, C.A.; Pritchard, R.G.; Teat, S.J.; et al. Rings and threads as linkers in metal-organic frameworks and poly-rotaxanes. Chem. Commun. 2013, 49, 7195-7197. [CrossRef]

12. Clegg, J.K.; Li, F.; Jolliffe, K.A.; Lindoy, L.F.; Meehan, G.V.; Parsons, S.; Tasker, P.A.; White, F.J. Hierarchical assembly of discrete copper(II) metallo-structures from pre-assembled dinuclear (bis- $\beta$-diketonato) metallocycles and flexible difunctional co-ligands. Dalton Trans. 2013, 42, 14315-14323. [CrossRef] [PubMed]

13. Clegg, J.K.; Iremonger, S.S.; Hayter, M.J.; Southon, P.D.; Macquart, R.B.; Duriska, M.B.; Jensen, P.; Turner, P.; Jolliffe, K.A.; Kepert, C.J.; et al. Hierarchical Self-Assembly of a Chiral Metal-Organic Framework Displaying Pronounced Porosity. Angew. Chemie Int. Ed. 2010, 49, 1075-1078. [CrossRef] [PubMed]

14. Clegg, J.K.; Bray, D.J.; Gloe, K.; Gloe, K.; Jolliffe, K.A.; Lawrance, G.A.; Lindoy, L.F.; Meehan, G.V.; Wenzel, M. Synthetic, structural, electrochemical and solvent extraction studies of neutral trinuclear $\mathrm{Co}(\mathrm{II}), \mathrm{Ni}(\mathrm{II})$, $\mathrm{Cu}(\mathrm{II})$ and $\mathrm{Zn}(\mathrm{II})$ metallocycles and tetrahedral tetranuclear Fe(III) species incorporating 1,4-aryl-linked bis- $\beta$-diketonato ligands. Dalton Trans. 2008, 1331-1340. [CrossRef] [PubMed]

15. Clegg, J.K.; Gloe, K.; Hayter, M.J.; Kataeva, O.; Lindoy, L.F.; Moubaraki, B.; McMurtrie, J.C.; Murray, K.S.; Schilter, D. New discrete and polymeric supramolecular architectures derived from dinuclear (bis- $\beta$-diketonato) copper(II) metallocycles. Dalton Trans. 2006, 3977-3984. [CrossRef]

16. Rancan, M.; Tessarolo, J.; Zanonato, P.L.; Seraglia, R.; Quici, S.; Armelao, L. Self-assembly of a constitutional dynamic library of $\mathrm{Cu}(\mathrm{II})$ coordination polygons and reversible sorting by crystallization. Dalton Trans. 2013, 42, 7534-7538. [CrossRef]

17. Rancan, M.; Dolmella, A.; Seraglia, R.; Orlandi, S.; Quici, S.; Armelao, L. A templating guest sorts out a molecular triangle from a dimer-trimer constitutional dynamic library. Chem. Commun. 2012, 48, 3115-3117. [CrossRef]

18. Rancan, M.; Tessarolo, J.; Casarin, M.; Zanonato, P.L.; Quici, S.; Armelao, L. Double Level Selection in a Constitutional Dynamic Library of Coordination Driven Supramolecular Polygons. Inorg. Chem. 2014, 53, 7276-7287. [CrossRef]

19. Rancan, M.; Tessarolo, J.; Quici, S.; Armelao, L. Post-assembly guest oxidation in a metallo-supramolecular host and structural rearrangement to a coordination polymer. Chem. Commun. 2014, 50, 13761-13764. [CrossRef]

20. Janiak, C. A critical account on $\pi-\pi$ stacking in metal complexes with aromatic nitrogen-containing ligands. J. Chem. Soc. Dalton Trans. 2000, 3885-3896. [CrossRef]

21. Sluch, I.M.; Miranda, A.J.; Elbjeirami, O.; Omary, M.A.; Slaughter, L.M. Interplay of Metallophilic Interactions, $\pi-\pi$ Stacking, and Ligand Substituent Effects in the Structures and Luminescence Properties of Neutral Pt II and Pd II Aryl Isocyanide Complexes. Inorg. Chem. 2012, 51, 10728-10746. [CrossRef]

22. Musumeci, C.; Osella, S.; Ferlauto, L.; Niedzialek, D.; Grisanti, L.; Bonacchi, S.; Jouaiti, A.; Milita, S.; Ciesielski, A.; Beljonne, D.; et al. Influence of the supramolecular order on the electrical properties of 1D coordination polymers based materials. Nanoscale 2016, 8, 2386-2394. [CrossRef] [PubMed]

23. Akine, S.; Shimada, T.; Nagumo, H.; Nabeshima, T. Highly cooperative double metalation of a bis $\left(\mathrm{N}_{2} \mathrm{O}_{2}\right)$ ligand based on bipyridine-phenol framework driven by intramolecular $\pi$-stacking of square planar nickel(II) complex moieties. Dalton Trans. 2011, 40, 8507-8509. [CrossRef] [PubMed]

24. Kammer, S.; Müller, H.; Grunwald, N.; Bellin, A.; Kelling, A.; Schilde, U.; Mickler, W.; Dosche, C.; Holdt, H.J. Supramolecular Assemblies with Honeycomb Structures by $\pi-\pi$ Stacking of Octahedral Metal Complexes of 1,12-Diazaperylene. Eur. J. Inorg. Chem. 2006, 2006, 1547-1551. [CrossRef]

25. Constable, E.C.; Housecroft, C.E.; Vujovic, S.; Zampese, J.A. Metallohexacycles containing 4'-aryl-4,2':6', $4^{\prime \prime}$-terpyridines: Conformational preferences and fullerene capture. CrystEngComm 2014, 16, 328-338. [CrossRef] 
26. Tzeng, B.C.; Lin, J.F. Crystal-engineering and luminescence studies of 1,3,5-tris (3-pyridylethynyl) benzene or 1,3,5-tris (4-pyridylethynyl) benzene with copper(I) iodides. Dalton Trans. 2019, 48, 4046-4057. [CrossRef]

27. Ju, H.; Lee, E.; Kim, S.; Park, I.H.; Lee, J.H.; Lee, S.S. Cation-directed assembly of polyrotaxane and polycatenane. CrystEngComm 2016, 18, 2621-2625. [CrossRef]

28. Zhang, S.Q.; Jiang, F.L.; Wu, M.Y.; Ma, J.; Bu, Y.; Hong, M.C. Assembly of discrete one-, two-, and three-dimensional $\mathrm{Zn}(\mathrm{II})$ complexes containing semirigid V-shaped tricarboxylate ligands. Cryst. Growth Des. 2012, 12, 1452-1463. [CrossRef]

29. Wang, C.Y.; Wilseck, Z.M.; Laduca, R.L. $1 \mathrm{D}+1 \mathrm{D} \rightarrow 1 \mathrm{D}$ polyrotaxane, 2D $+2 \mathrm{D} \rightarrow 3 \mathrm{D}$ interpenetrated, and 3D self-penetrated divalent metal terephthalate bis (pyridylformyl) piperazine coordination polymers. Inorg. Chem. 2011, 50, 8997-9003. [CrossRef]

30. Gao, X.M.; Li, D.S.; Wang, J.J.; Fu, F.; Wu, Y.P.; Hu, H.M.; Wang, J.W. A novel 1D armed-polyrotaxane chain constructed from a V-shaped tetracarboxylate ligand. CrystEngComm 2008, 10, 479-482. [CrossRef]

31. Hazari, D.; Jana, S.K.; Puschmann, H.; Zangrando, E.; Dalai, S. 1D lead(II) coordination chains with carboxylate containing ligands. A rare example of polyrotaxane $1 \mathrm{D} \rightarrow 1 \mathrm{D}$ interpenetrated coordination polymer. Inorg. Chem. Commun. 2016, 65, 1-3. [CrossRef]

(C) 2019 by the authors. Licensee MDPI, Basel, Switzerland. This article is an open access article distributed under the terms and conditions of the Creative Commons Attribution (CC BY) license (http://creativecommons.org/licenses/by/4.0/). 